\title{
TEKNIK PEMBENIHAN IKAN MAS (Cyprinus carpio) SECARA ALAMI DI UNIT PELAKSANA TEKNIS PENGEMBANGAN BUDIDAYA AIR TAWAR (UPT PBAT) UMBULAN, PASURUAN
}

\author{
Natural Technique of Carp Fish Nursery in Technical Implementation Unit of \\ Development of Umbulan, Pasuruan
}

\author{
Rizqi Ramadhan ${ }^{1 *}$ dan Luthfiana Aprilianita Sari². \\ ${ }^{1}$ Program Studi Budidaya Perairan, Fakultas Perikanan dan Kelautan, Universitas Airlangga, Surabaya \\ ${ }^{2}$ Departemen Manajemen Kesehatan Ikan dan Budidaya Perairan, Fakultas Perikanan dan Kelautan, Universitas \\ Airlangga, Surabaya \\ *rizqi.ramadhan-2015@fpk.unair.ac.id
}

\begin{abstract}
Abstrak
Praktek Kerja Lapang (PKL) dilaksanakan di Unit Pelaksana Teknis Pengembangan Budidaya Air Tawar Umbulan, Kabupaten Pasuruan, Provinsi Jawa Timur pada tanggal 18 Desember 2017 - 18 Januari 2018. Tujuan dari Praktek Kerja Lapang ini adalah untuk mengetahui secara langsung serta mendapatkan pengalaman secara jelas tentang teknik pembenihan ikan mas (Cyprinus carpio) dalam pengembangan lebih lanjut dan permasalahan dalam usaha pembenihan ikan mas yang di hadapi serta cara pemecahannya. Metode yang di gunakan pada PKL ini adalah metode deskriptif, dengan teknik pengambilan data meliputi data primer dan data sekunder. Pengumpulan data ini dilakukan secara observasi, wawancara dan partisipasi aktif. UPT PBAT Umbulan memiliki luas keseluruhan lahan 6,25 hektar. Pemijahan ikan mas dilakukan secara alami. Induk ikan mas yang digunakan berasal dari Punten dan Sukabumi. Perbandingan berat induk ikan mas antara jantan dan betina yaitu 2 : 1 . Parameter Kualitas air untuk pembenihan ikan mas Antara lain : suhu 26,6-31,05 ${ }^{\circ} \mathrm{C}$; $\mathrm{pH}$ 7,17,36; dan DO 6,23-10,8 mg/l. Berdasarkan hasil perhitungan, didapatkan nilai Fertilization Rate (FR) telur ikan mas sebesar 91,73\%, Hatching Rate (HR) ikan mas sebesar 74,4\% serta Survival Rate (SR) sebesar 30,44\%. Pakan buatan yang digunakan dalam pemeliharan benih adalah pellet HI-PRO-VITE 781-3 yang telah dihaluskan dengan kadar protein 31\%-33\%. Benih ikan mas yang dipanen di UPT PBAT Umbulan memiliki ukuran 1-3 cm. UPT PBAT Umbulan mampu memproduksi benih sebanyak 50.000-100.000 ekor setiap bulan dengan harga benih diangka 10 Rp per benih ukuran 1-2 cm dan 50 Rp per benih ukuruan $5 \mathrm{~cm}$.
\end{abstract}

Kata kunci: Ikan Mas, Teknik Pembenihan Alami dan UPT PBAT Umbulan

\begin{abstract}
Field work practice singer has performed in the Technical Services Unit Development of Freshwater Aquaculture Umbulan, Pasuruan, East Java, on December $18^{\text {th }}, 2017$ to January $18^{\text {th }}$, 2018. The purpose of the Field work practice is to know directly as well as gaining experience in a clear and direct seeding techniques on carp (Cyprinus carpio). In a further development and problems in the hatchery business carp as well as the solution. The method used in this PKL is descriptive method, with the techniques of data collection that includes the primary data and secondary data. Data collection was conducted by observations, interviews, and active praticipation. Technical Services Unit Development of Freshwater Aquaculture Umbulan has a total 6,25 acres land. The Carp spawning techniques is using natural spawning technique. The carp broodstocks are from Punten and Sukabumi. Comparation of the weight of the male and female broodstock are 2:1. Water quality parameters for carp hatcheries are : Temperature 26,6-31,05 ${ }^{\circ} \mathrm{C}$; $\mathrm{pH}$ 7,1-7,36; DO 6,23-10,8 mg/l. Based on the calculation, obatined the fertilization rate (FR) of the carp eggs by $74,4 \%$, hatching rate (HR) by $74,4 \%$ and survival rate (SR) by $30,44 \%$. Artificial feed used in maintenance is HI-PRO-VITE 781-3 that has a protein content of 31\%$33 \%$. Harvested carp seeds have size of $1-3 \mathrm{~cm}$. Technical Services Unit Development of Freshwater Aquaculture Umbulan able to produce seeds as many as 50.000-100.000 every month with price of 10-50 rupias per seed.
\end{abstract}

Keywords: Carp, Seed Techniques and UPT PBAT Umbulan 


\section{PENDAHULUAN}

Dewasa ini kebutuhan masyarakat akan protein semakin meningkat, oleh sebab itu pemerintah berupaya untuk mencari alternatif dalam peningkatan mutu gizi masyarakat terutama dalam hal kebutuhan protein. Salah satu sumber pangan yang dapat menjadi alternatif yaitu ikan, karena mengandung protein yang cukup tinggi. Ikan merupakan sumber protein yang paling murah bila dibandingkan dengan sumber protein hewani lain (Sugeng, 1990).

Ikan mas merupakan salah satu jenis ikan konsumsi yang mempunyai nilai ekonomis penting. Menurut Saprianto (2010) permintaan untuk ikan mas cukup tinggi. Jumlah untuk wilayah Jakarta, Bogor, Depok dan Bekasi (Jabodetabek) dapat mencapai 50 ton setiap hari, jumlah tersebut belum termasuk permintaan dari kota lain. Jumlah permintaan komoditas ikan mas diperkirakan meningkat pada kisaran 100 ton per-hari. Jumlah tersebut harus diimbangi dengan pemasokan ikan mas secara kontinu.

Benih ikan mas yang unggul dalam kualitas dan kuantitas tidak lepas dari peranan kegiatan pembenihan. Kegiatan pembenihan ini ditujukan untuk mendapat benih secara kontinu yang memenuhi permintaan pasar, sehingga dapat menghasilkan keuntungan dari segi ekonomi. Tanpa pembenihan, subsistem yang lain tidak akan dapat berjalan karena kegiatan pendederan dan pembesaran sangat memerlukan benih yang merupakan produk dari kegiatan pembenihan. Proses pembesaran benih juga memerlukan penanganan yang baik agar benih ikan mas yang dihasilkan dapat tumbuh dengan optimal, sehingga dapat memenuhi standar penjualan (Susanto, 2006).

Kegiatan yang dilakukan dalam teknik pembenihan ikan mas secara alami meliputi sarana persiapan kolam, seleksi induk, pemijahan, pemeliharaan telur dan larva, pendederan, pengelolaan kualitas air, perhitungan Fertilization Rate (FR), Hatching Rate (HR), dan Survival Rate (SR), serta pengendalian hama dan penyakit. Keterampilan dan pengetahuan tentang teknik pembenihan ikan mas yang baik dapat menunjang keberhasilan dalam usaha tersebut, sehingga diharapkan dapat meningkatkan kualitas dan produktifitas ikan mas. Salah satu usaha yang dilakukan untuk memperoleh pengetahuan tersebut adalah melakukan Praktek Kerja Lapang tentang teknik pembenihan ikan mas secara alami di UPT-PBAT Umbulan, Kabupaten Pasuruan, Jawa Timur.

\section{METODOLOGI \\ Waktu dan Tempat}

Praktek Kerja Lapang (PKL) ini telah di laksanakan di Unit Pelaksana Teknis Pengembangan Budidaya Air Tawar (UPT PBAT) Umbulan, Pasuruan, Jawa Timur. Kegiatan dilaksanakan pada tanggal 18 Desember 2017 - 18 Januari 2018.

\section{Metode Penelitian}

Metode kerja yang digunakan dalam PKL ini adalah metode deskriptif. Menurut Suryabrata (1993), metode deskriptif adalah suatu metode yang bertujuan untuk membuat gambaran secara sistematis, faktual, dan akurat mengenai fakta dan sifat populasi dari suatu kegiatan di daerah tertentu. Pengumpulan data pada PKL ini adalah dengan pengumpulan data primer dan data sekunder dengan beberapa metode. Data primer merupakan data yang didapat secara langsung dari sumber asli (tidak melalui perantara), dengan teknik pengambilan data berupa wawancara / tanya jawab, observasi, partisipasi aktif maupun memakai instrumen pengukuran yang khusus sesuai dengan tujuan (Azwar, 1998). Sedangkan menurut Azwar (1998) data sekunder adalah data yang diperoleh dari sumber tidak langsung dan telah dikumpulkan serta dilaporkan oleh orang di luar dari penelitian itu sendiri.

\section{HASIL DAN PEMBAHASAN}




\section{Teknik Pemeliharaan Benih Ikan Koi (Cyprinus carpio)}

Pelaksanaan teknik pembenihan ikan mas mencakup beberapa proses yaitu persiapan kolam, seleksi induk, pelepasan induk, pemijahan, penetasan telur, perawatan larva, pendederan, pemanenan, packing, Pengelolaan kualitas air, pengendalian hama dan penyakit. Seluruh kegiatan tersebut dikontrol agar panen yang didapatkan optimal.

\section{Persiapan Kolam}

Rangkaian dari proses pembenihan ikan mas di UPT PBAT Umbulan diawali dari persiapan kolam pemijahan, kolam yang digunakan di yaitu kolam beton berukuran $15 \times 5 \times 1 \mathrm{~m}$ dengan dasar beton. Persiapan kolam berupa pembersihan dasar kolam yang telah kering dari cangkang keong dan sisa organisme yang telah mengering menggunakan sapu lidi tujuan dari pembersihan ini agar kotoran tersebut tidak menjadi sumber penyakit. Menurut Effendi (2003), sumber amonia di perairan merupakan hasil pemecahan nitrogen organik (nitrogen dan urea) dan nitrogen anorganik yang terdapat di dalam tanah dan air, yang berasal dari proses dekomposisi bahan-bahan organik (tumbuhan dan biota akuatik yang telah mati) oleh mikroba dan jamur.

Langkah selanjutnya yaitu pengisian air ke dalam kolam dengan membuka saluran inlet dan menutup saluran outlet yang telah dipasang saringan untuk mencegah kotoran masuk dan keluarnya larva ikan. Air diisi hingga mencapai ketinggian $30 \mathrm{~cm}$ dari dasar kolam. Debit air kolam pemijahan sebesar 0,733 l/detik. Tahap selanjutnya yaitu pemasangan waring dan kakaban. Waring yang digunakan berukuran $2 \times 1 \times 1 \mathrm{~m}$ dengan mesh size $0,1 \mathrm{~cm}$ dipasang dengan diberi pemberat disetiap ujung waring dan kakaban yang digunakan terbuat dari lembaran jaring yang telah dipotong berbentuk persegi panjang sebanyak \pm 80 lembar dengan lebar 40-50 cm yang dijepit dengan 2 bilah bambu berukuran $1 \mathrm{~m}$ dan diberi pemberat berupa batu, jumlah kakaban yang digunakan sebanyak 4 buah. Fungsi dari kakaban dan waring yaitu sebagai tempat melekat telur ikan mas.

\section{Seleksi Induk}

Seleksi induk di UPT PBAT Umbulan dilakukan di kolam pemeliharaan induk, induk ikan mas berasal dari Punten dan Sukabumi, proses seleksi dilakukan melalui dua tahap yaitu seleksi berdasarkan jenis kelamin dan berdasarkan perbandingan berat induk ikan. Seleksi tahap pertama berdasarkan penentuan jenis kelamin yaitu dengan metode stripping pada bagian perut. Ikan mas jantan apabila dilakukan stripping akan mengeluarkan cairan sperma berwarna putih susu kental, sedangkan ikan mas betina terlihat membengkak pada bagian perut ke arah urogenital dan apabila di stripping akan mengeluarkan cairan berwarna kuning.

Seleksi tahap kedua yaitu berdasarkan peebandingan berat induk ikan yang akan dipijahkan. Perbandingan berat, indukan yang digunakan yaitu $2 \mathrm{~kg}$ jantan banding $1 \mathrm{~kg}$ betina (2:1) dengan tujuan agar telur dari induk betina dapat dibuahi secara maksimal oleh sperma pejantan. Menurut Saputra (2011), induk betina matang kelamin ditandai dengan gerakan yang lamban, perut membesar atau buncit kearah belakang, jika di raba terasa lunak, lubang anus agak menonjol atau membengkak, dan bila dilakukan pemijatan perlahan kearah anus maka akan keluar cairan kuning kemerahan. Untuk induk jantan, gerakan lincah, bandan ramping, jika diurut kearah anus maka akan mengeluarkan cairan sperma berwarna putih. Hasil seleksi ikan mas UPT PBAT umbulan didapatkan ikan mas jantan sebanyak 5 ekor Dengan total berat $2 \mathrm{~kg}$ dan ikan mas betina sebanyak 3 ekor dengan total berat $1 \mathrm{~kg}$.

\section{Pelepasan Induk}

Induk ikan mas di UPT PBAT Umbulan yang telah diseleksi kemudian dilepas di kolam pemijahan pada pukul 
10.00 dengan melalui proses pengangkutan secara terbuka dari kolam induk menuju kolam pemijahan karena jarak antara kolam pemeliharaan induk dengan kolam pemijahan $\pm 10 \mathrm{~m}$. Induk diangkut dengan menggunakan kantong plastik berukuran 150x50x0,5 cm ditambah dengan air sebanyak \pm 5 liter. Kantong plastik yang digunakan berupa kantong plastik rangkap dua dengan bagian tengah plastik diikat, kemudian dibalik sehingga posisi ikatan berada di dalam kantong dengan tujuan agar plastik tidak mudah bocor. Menurut Ismail dan Khumaidi (2016), waktu pelepasan induk yang baik yaitu pada waktu pagi dan sore hari karena pada waktu tersebut suhu perairan cenderung rendah. Proses pelepasan induk ikan dapat dilihat pada.

\section{Pemijahan}

Pemijahan ikan mas di UPT PBAT Umbulan dilakukan secara alami yaitu dengan meletakkan induk jantan dan betina dalam satu kolam tanpa diberi perlakukan khusus dan hanya menggunakan kakaban serta waring sebagai substrat sebagai tempat telur melekat. Pemijahan ikan mas terjadi sekitar pukul 22.00 - 03.00, proses pemijahan ditandai dengan bunyi percikan air yang dihasilkan akibat proses pengejaran induk betina oleh pejantan.

Menurut Ismail dan Khumaidi (2016), ikan mas memijah pada pukul 22.00 sampai menjelang subuh ditandai dengan aktifitas induk jantan yang mengejar induk betina. Induk betina akan mengeluarkan telur menjelang tengah malam pada kakaban dan waring dan diikuti oleh induk jantan yang mengeluarkan cairan sperma berwaran putih. Pukul 05.00 dilakukan pengamatan kembali pada kolam pemijahan, telur ikan mas terlihat menempel pada kakaban dan waring, kemudian dilakukan pemindahan induk ikan mas dari kolam pemijahan. Tujuan dari pemisahan induk setelah memijah yaitu agar telur yang baru menempel tidak dimakan oleh induk ikan mas.

Perhitungan jumlah telur menggunakan metode transek 10x10 cm dengan jumlah telur ikan mas yang dikeluarkan sebanyak 109.890 butir, telur yang dibuahi sebanyak 100.806 butir dan telur yang tidak dibuahi 9084 butir dengan nilai Fertilization Rate (FR) sebesar 91,73\%.

\section{Penetasan Telur}

Penetasan telur ikan mas di UPT PBAT Umbulan berlangsung selama +48 jam. Pada saat telur sudah menetas, waring dan kakaban diangkat dan dibersihkan. Telur yang sudah menetas akan menjadi larva, sedangkan telur yang gagal menetas akan berwarna putih yang menandakan telur mengalami kematian. Penyebab kematian telur dapat disebabkan oleh beberapa faktor antara lain pembuahan yang tidak sempuma dan kondisi telur yang saling menempel atau saling tindih pada saat penyebaran di waring sehingga sirkulasi oksigen terganggu dan menyebabkan kematian (Setyono, 2009).

Menurut Saputra (2011), faktor yang mempengaruhi keberhasilan penetasan telur ikan mas adalah kematangan gonad pada induk ikan dan kualitas air. Suhu optimal pada penetasan telur ikan mas adalah $26-28{ }^{\circ} \mathrm{C}$ (Cholik et $a l, 1986)$. Telur ikan mas yang menetas diperkirakan sebanyak 75000 butir dengan Nilai Hatching Rate (HR) didapatkan sebesar 74,4\%. Menurut Richter dan Rustidja (1985), Presentase penetasan ikan secara normal berkisar antara 5080\%. Hatching Rate larva ikan mas di UPT PBAT Umbulan yaitu sebesar $74,4 \%$.

\section{Perawatan Larva}

Perawatan larva merupakan hal yang penting dalam pembenihan ikan karena mortalitas tinggi. Menurut Saputra (2011), larva ikan merupakan fase yang paling kritis dalam budidaya ikan karena 
larva ikan mempunyai ketahanan yang kurang baik dan rentan pada perubahan kondisi lungkungan. 48 jam setelah menetas cadangan makanan pada larva akan habis, sehingga diperlukan asupan gizi tambahan, pakan yang diberikan berupa kuning telur yang telah direbus matang kemudian kuning telur di ayak diatas air menggunakan saringan sampai merata. Pemberian kuning telur diberikan selama $2 x$ sehari pagi hari dan sore hari selama 3 hari.

Perlakuan lain selama perawatan larva yaitu pemberian pupuk, pemupukan dilakukan dengan metode Pulling, Metode Pulling adalah pemupukan pada beberapa lokasi perairan dengan maksud mineralisasi terjadi secara bertahap (Akbar, 2016). Pupuk yang digunakan berasal dari kotoran kambing dengan dosis pupuk sebanyak $7 \mathrm{~kg}$ yang telah dikemas dalam karung beras berukuran 35 Kg yang telah di beri lubang kecil di setiap permukaan karung. Pemberian pupuk bertujuan menumbuhkan pakan alami yang diperlukan larva yang telah menghabiskan cadangan kuning telur.

Menurut Akbar (2016), salah satu cara untuk penyediaan pakan ikan di kolam selain pemberian pakan buatan, yaitu dengan cara memberi pupuk dengan tujuan meningkatkan jumlah pakan alami ikan dan mampu meningkatkan produksi ikan yang dipelihara. Pupuk kandang diberikan setelah indukan dikembalikan, hal ini disebabkan ketidak tersediaan kolam sehingga kolam pemijahan akan langsung digunakan sebagai kolam pendederan. Larva akan dipelihara dalam kolam selama 1 bulan.

\section{Pendederan}

Pendederan larva ikan mas di UPT PBAT Umbulan dilakukan dikolam pemijahan dikarenakan keterbatasan kolam, kolam yang telah di beri pupuk kandang akan memiliki warna air yang kehijauan karena terdapat pakan alami berupa fitoplankton, larva juga diberi pakan tambahan berupa pellet HI-PRO-
VITE 781-3 kadar protein 31-33\%, menurut Masitoh et al. (2015), kebutuhan protein dalam tubuh benih ikan mas minimal 30\%. Pelet yang telah dihaluskan menggunakan mesin slep diberikan kepada benih dengan metode blind feeding menurut Poh (2014), blind feeding adalah panduan pemberian pakan yang dikembangkan oleh pabrik atau petani perorangan didasarkan pada percobaan.

Dosis pakan yang digunakan pada minggu pertama sebanyak 50 gr, dengan frekuensi pemberian 2x1 hari. Pemberian pakan tambahan dilakukan dengan mencampurkan pelet serbuk dengan air dalam suatu wadah hingga cair kemudian disebar merata pada kolam pendederan. Pada minggu ke-dua larva diberi pelet serbuk sebanyak 100 gr 2x1 hari dan minggu ke 3 diberi pakan serbuk sebanyak 200 gr 2x1, selama pendederan ketinggian air pada kolam akan di jaga pada kisaran $30 \mathrm{~cm}$ dengan cara mengatur debit air yang masuk.

Pertumbuhan panjang dan berat larva ikan diukur sebanyak 1 minggu sekali. Hasil sampling benih ikan mas didapatkan nilai pertambahan panjang $0,186 \mathrm{~cm}$ dan 0,02452 gram perminggu. Menurut Utomo, dkk (2005) konversi dan efisiensi pakan memiliki hubungan dengan nilai kecernaan yang menggambarkan persentase nutrien yang dapat diserap oleh saluran pencernaan tubuh ikan, semakin besar nilai kecernaan suatu pakan maka semakin banyak pula nutrien pakan yang dapat dimanfaatkan oleh ikan tersebut. Penyerapan nutrien oleh tubuh organisme dipengaruhi oleh berbagai hal seperti kualitas pakan dan jumlah pakan yang dikonsumsi, nutrien yang dimanfaatkan oleh ikan mas dapat mempengaruhi penyediaan energi protein dan non protein dalam tubuh, semakin banyak energi yang tersedia dalam tubuh akan meningkatkan kemampuan ikan mas untuk mengubah energi tersebut dan disimpan dalam bentuk daging (protein dan lemak) (Akbar, 2000). 


\section{Pemanenan}

Pemanenan Benih Ikan mas di UPT PBAT Umbulan dimulai pukul 05.00 WIB dimulai dari pengurangan air dengan cara memasang saringan dan membuka outlet, dibutuhkan waktu \pm 4 jam untuk menurunkan air hingga ketinggian $5 \mathrm{~cm}$, selama proses penurunan air dilakukan pemasangan tanjaran pada saluran dekat outlet bertujuan untuk menampung benih ikan agar mudah dipindahkan, proses pemanenan dilakukan secara perlahan dikarenakan terdapat banyak lumut yang ada pada kolam, lumut dapat menyumbat saringan pada outlet yang menyebabkan benih susah keluar dan dapat menyebabkan ikan menjadi stress karena kekurangan oksigen.

Benih dan lumut yang telah masuk tanjaran akan dipisah menggunakan saringan bulat dengan Mesh Size 0,1 cm dan dimasukkan dalam ember yang kemudian akan di pindah ke dalam tanjaran yang berada pada saluran inlet, ember bersisi benih akan dituangkan di sisi kiri tanjaran dan benih digiring menuju kanan tanjaran proses ini bertujuan untuk memisahkan kotoran yang ikut selama proses pemanenan. Pemanenan ini merupakan pemanenan total, Menurut Sutisna dan Sumartono (1995), pemanenan total adalah pemanenan benih yang dilakukan secara sekaligus dengan mengeringkan kolam.

Benih ikan mas yang telah dipanen kemudian dihitung secara manual dan didapatkan benih sebanyak 22828 ekor serta nilai Survival Rate (SR) sebesar 30,44 \% dengan ukuran benih 1-4 cm. nilai Nilai SR yang diperoleh kurang bagus dimana Mokodongan (2009) menyatakan, tingkat mortalitas pada pembenihan ikan mas secara alami adalah 35-75 \%, nilai SR yang rendah dan laju pertumbuhan yang tidak sama disebabkan tidak dilakukan pergantian kolam pada tahap pendederan. Faktor yang mempengaruhi kelulushidupan adalah faktor biotik dan abiotic, faktor biotik meliputi kemampuan berenang, menangkap makanan, tingkat stres, dan umur, sedangkan faktor abiotik yang mempengaruhi adalah ketersediaan pakan dan kualitas air. Survival Rate larva ikan mas di UPT PBAT Umbulan yaitu sebesar $30,44 \%$.

Benih yang telah dipanen dapat dipindah menuju kolam pendederan lanjutan atau dimasukkan kedalam kolam pemberokan pada bangsal panen untuk dijual. Benih ikan sebelum ditransportasikan harus dipuasakan atau diberok terlebih dahulu dengan tujuan mengurangi kotoran atau sisa metabolisme (Khairuman dkk, 2008). Benih ikan yang telah dipanen diberok selama 2-6 jam bergantung dari jarak transportasi.

\section{Packing}

Benih ikan mas berukuran 1-3 cm yang telah diberok selama 2-6 jam akan di packing dalam plastik rangkap dengan jumlah 1000-2000 ekor benih per plastik dengan perbandingan antara air dengan oksigen sebesar 1:2. Jarak tempuh yang mampu dilalui oleh benih sangat bergantung pada kepadatan dalam plastik packing dan ukuran dari benih tersebut, semakin padat dan besar ikan maka semakin rendah jarak tempuh.

Pescod (1973) menyatakan, bahwa kandungan $\mathrm{O} 2$ terlarut yang baik untuk ikan harus lebih dari $2 \mathrm{mg} / \mathrm{l}$, apabila media pengangkutan memiliki kandungan oksigen terlarut kurang dari 2 mg/l maka akan menyebabkan kematian. Harga benih ikan mas berukuran 1-2 cm sebesar 10 Rupiah per benih sedangkan ukuran $5 \mathrm{~cm}$ sebesar 50 Rupiah per benih. Pengiriman benih ikan mas UPT PBAT Umbulan baru mencangkup wilayah jawa timur dengan benih yang dipesan dikisaran 50.000100.000 benih perbulan.

\section{Pengelolaan Kualitas Air}

Air yang digunakan sebagai media pemeliharaan induk, larva serta benih ikan mas di UPT PBAT Umbulan menggunakan air dari mata air umbulan yang dialirkan langsung menuju kolam 
melalui saluran air. tidak ada perlakuan khusus dalam pengelolaan air yang masuk, hanya dipasang beberapa besi pada saluran masuk pertama sebagai penghalang sampah agar tidak masuk ke dalam kolam.

Pengecekan kualitas air dilakukan setiap hari pada pagi hari (08.00 WIB) dan sore hari (15.00 WIB) menggunakan alatalat yang telah disediakan, seperti: suhu air melalui thermometer, $\mathrm{pH}$ air melalui $\mathrm{pH}$ meter, DO melalui DO meter, kecerahan melalui secchi disk, serta dilakukan dilakukan pemeriksaan kualitas air lanjutan setiap 1 minggu sekali. Hal tersebut dilakukan untuk memastikan bahwa lingkungan tempat hidup ikan mas telah memenuhi syarat teknis yang baik dan benar.

Perubahan kualitas air yang sering terjadi selama proses pemeliharaan larva yaitu fluktuasi suhu, faktor cuaca sangat mempengaruhi hal tersebut, Suhu air sumber dikisaran $22-24{ }^{\circ} \mathrm{C}$ dan suhu pada kolam berada pada kisaran $25-33{ }^{\circ} \mathrm{C}$. Menurut SNI (1999), nilai suhu yang cocok untuk budidaya ikan mas adalah 25$30{ }^{\circ} \mathrm{C}$, sehingga perlu dilakukan pengaturan debit air, agar suhu mengurangi fluktuasi suhu dan tetap mampu menstabilkan ketinggian air di kisaran $30 \mathrm{~cm}$.

\section{Pengendalian Hama Dan Penyakit}

Pengendalian hama dan penyakit merupakan suatu upaya untuk menghindarkan larva atau benih ikan mas terserang hama dan penyakit. Pada kolam pemeliharaan larva, hama yang biasa menyerang adalah katak dan kecebong (anak katak). Katak dan kecebong tersebut akan memakan pakan ikan mas. Penanggulangan dilakukan secara fisik dengan menangkap indukan katak menggunakan jaring kemudian dibuang, agar tidak bertelur pada kolam pemeliharaan larva. Pada masa pemeliharaan larva ini sering muncul hama dikarenakan lokasi kolam pemeliharaan larva terdapat pada ruang terbuka. Pengelolaan kolam sangat mempengaruhi kelulushidupan dan kualitas ikan yang dipelihara, terutama mengenai perairan kolam, perairan kolam yang tidak sesuai menimbulkan berbagai macam penyakit ikan (Handajani \& Widodo, 2010).

\section{KESIMPULAN DAN SARAN Kesimpulan}

Teknik pembenihan ikan mas (Cyprinus carpio) di UPT PBAT Umbulan dilakukan secara alami, induk ikan mas yang digunakan berasal dari Punten dan Sukabumi dengan menggunakan perbandingan induk jantan dan betina 2:1, metode pemberian pakan yaitu Blind Feeding, didapatkan nilai FR 91,73\% ,HR 75\% dan SR 30,44\%. Kualitas air pada kolam pemeliharan yaitu : suhu 26,5831,05 ${ }^{\circ} \mathrm{C}$, DO 6,23-10,8 mg/l dan $\mathrm{pH}$ $7,1-7,36$. Permasalahan yang dialami pada kegiatan pembenihan ikan mas secara alami di UPT PBAT Umbulan meliputi ketersediaan induk matang gonad, hama yang menyerang benih, dan keterbatasan tenaga kerja yang menangani masalah pembenihan.

\section{Saran}

UPT PBAT Umbulan, Pasuruan perlu menerapkan teknik pemijahan buatan pada komoditas ikan mas seperti penggunaan teknik In Vivo atau penggunaan Ovaprim pada Induk agar mampu meningkatkan kualitas dan kuantitas benih ikan mas. UPT PBAT Umbulan, Pasuruan juga perlu menggunakan tandon pengendapan air agar suhu air yang digunakan dapat distabilkan terlebih dahulu, sehingga tidak terjadi fluktuasi suhu yang besar antara air sumber dan air pada kolam, yang dapat mengakibatkan SR rendah.

\section{DAFTAR PUSTAKA}

Akbar, J. 2016. Pengantar Ilmu Perikanan dan Kelautan (Budidaya Perairan). 
Lambung Mangkurat University Press. Hal. 20-38.

Azwar, S. 1998. Metode Penelitian. Pustaka Pelajar. Yogyakarta. 146 hal.

Bachtiar, Y. 2000. Pembesaran Ikan Mas di Kolam Pekarangan. Agromedia Pustaka Jakarta. 80 hal.

Boyd, C. T. 1990. Water Quality in Pond for Aquaculture. Birmingham. Publ.Co. Alabama. 482 hal.

Cholik, F., Artati dan R. Arifudin. 1986. Pengelolaan Air dalam Kolam Ikan. Jakarta : Direktorat Jendral Perikanan. 52 Hal.

Daelami, D. 2001. Usaha Pembenihan Ikan Hias Air Tawar. Penerbit Swadaya. Jakarta. 166 hal.

Effendi, H. 2003. Telaah Kualitas Air bagi Pengelolaan Sumber Daya dan Lingkungan Perairan. Kanisius, Yogyakarta. 258 hal.

Effendie, M. I.1979. Metoda biologi perikanan. Yayasan Dewi Sri.Bogor. 112 hal.

Husniya, L., G. Abdul. dan L. Dwi. Pengaruh Jenih Pakan Terhadap Pertambahan Bobot dan Kelulushidupan Benih Ikan Mas (Cyprinus carpio L.) Strain Punten. Fakultas Biolog. Universitas Negeri Malang. Hal. 6.

Ismail, A. Khumaidi. 2016. Teknik Pembenihan Ikan Mas (Cyprinus carpio L.) di Balai Benih Ikan Tenggarang Bondowoso. Jurnal Ilmu Perikanan, 7(1) : 32.

Jangkaru, Z. 2003. Pembesaran Ikan Air Tawar di Berbagai Lingkungan. Penebar Swadaya. Jakarta. 96 hal.

Khairuman, D. S., dan B. Gunandi. 2008. Budidaya Ikan Mas secara Intensif. PT Agromedia Pustaka. Jakarta. 96 hal.

Komarudin, O., O. Praseno. dan Z. I. Azwar. 1991. Infeksi Parasit pada Benih Ikan Mas yang Dipelihara di Kolam dengan Sistem Aerasi. Buletin Penelitian Perikanan Darat. BRPBAT 10.
Kurniastuty, T. T. dan P. Hartono. 2004. Hama dan Penyakit Ikan dalam Pembenihan Ikan Kakap. Depertemen Kelautan dan Perikanan. Direktorat Jenderal Perikanan Budidaya. Balai Budidaya Laut Lampung. Bandar Lampung. Halaman 77.

Lembaga Informasi Pertanian. 2000. Ikan Mas Rajadanu. Instalasi Penelitian dan Pengkajian Teknologi Pertanian Mataram. Mataram. 4 hal.

Mahasri, G., A. S. Mubarok., M. A. Alamsjah., A. Manan. dan P. D. Wulansari. 2012. Manajemen Kualitas Air. Fakultas Perikanan dan Kelautan Universitas Airlangga Surabaya. Hal. 48-62.

Mantau, Z., J. B. M. Rawung dan Sudarty. 2004. Pembenihan Ikan Mas yang Efektif dan Efisien. Jurnal Litbang Pertanian 23(2) : 68-73.

Masitoh, D., Subandiyono. \& Pinandoyo. 2015. Pengaruh Kandungan Protein Pakan yang Berbeda dengan Nilai E/P 8,5 kkal/g Terhadap Pertumbuhan Ikan Mas (Cyprinus carpio). Journal of Aquaculture Management and Technology, 4 (3): 46-53.

Mukti, A. T., Rustidja, B. S. Sutiman dan, M. S. Djati. 2001. Poliploidisasi Ikan Mas (Cyprinus carpio L.). Biosain Jurnal Ilmu-ilmu Hayati I. Hal. 111-123.

Mokodongan A. D. 2009. Pembenihan Ikan Mas (Cyprinus carpio L.) pada Budidaya Air Tawar. $30 \mathrm{Hal}$.

Nazir, M. 1998. Metode Penelitian. Graha Indonesia. Jakarta. 622 hal.

Pescod, M.B. 1973. Investigation of Rational Effeluent and Standards for Tropical Countries. ASEAN Institute of Technology. Bangkok. 54 hal.

Poh, Y.T. 2014. Feed Management Improves Profit in Shrimp Farming. Global Aquaculture Advocate. Hal. 26. 
Richter, C.J.J dan Rustidja. 1985. Pengantar Ilmu Produksi Ikan. Malang : NUFFIC/Unibraw Luw/Fish. Hal. 69-71.

Rosidah dan W. M. Afizia. 2012. Potensi Ekstrak Daun Jambu Biji Sebagai Antibakterial Untuk Menanggulangi Serangan Bakteri Aeromonas hydrophilla pada ikan Gurame (Osphronemus gouramy lacepede). Jurnal Akuatik 8(1) : 19-27.

Santoso, B. 1993. Petumjuk Praktis Budidaya Ikan Mas. Kanisius. Yogyakarta. 83 hal.

Saprianto, C. 2010. Usaha Ikan Konsumsi Lahan $100 \mathrm{~m}^{2}$. Penebar Swadaya. Jakarta. Hal. 47.

Saputra, S.D. 2011. Aplikasi Sistem Resirkulasi Air Terkendali (SRAT) pada Budidaya Ikan Mas (Cyprinus carpio). Fakultas Teknologi Pertanian. Institut Pertanian Bogor. Hal. 5-27.

Setyono, B. 2009. Pengaruh Perbedaan Konsentrasi Bahan Pada Pengencer Sperma Ikan "Skim Kuning Telur” Terhadap Laju Fertilisasi, Laju Penetasan dan Sintasan Ikan Mas (Cyprinus carpio L.) Fakultas Pertanaian dan Peternakan. Universitas Muhammadiyah Malang. Hal 9.

SNI. 1999. Produksi Induk Ikan Mas (Cyprinus carpio Linneaus) strain Sinyonya kelas induk pokok. Jakarta : BSN. Hal. 4-8.

Subekti, S. dan G. Mahasri. 2010. Buku Ajar Parasit dan Penyakit Ikan (Trematodiasis dan Cestodiasis). Global Persada Press. Surabaya. 91 hal.

Sugeng, H.R. 1990. Beternak Ikan di Kolam. Aneka Ilmu. Semarang. 97 hal.

Suryabrata, S. 1993. Metode Penelitian. CV. Rajawali. Jakarta. 115 hal.

Susanto, H, 1990. Membuat Kolam Ikan. Penebar Swadaya. Jakarta. 96 hal.
Susanto, H. 1995. Budidaya Ikan di Pekarangan. Cetakan kesepuluh. Penebar Swadaya. Jakarta. Hal. 88-137.

Susanto, H. Dan Rochdianto. 1997. Kiat Budidaya Ikan Mas di Lahan Kritis. Penebar Swadaya. Jakarta. 132 hal.

Susanto, H. 2006. Arwana. Penebar Swadaya. Jakarta. 80 hal.

Suseno, D. 2003. Pengelolaan Usaha Pembenihan Ikan Mas. Penebar Swadaya. Jakarta. 74 hal.

Sutisnia, H dan R. Sutarmanto. 1995. Pembenihan Ikan Air Tawar. Kanisius. Yogyakarta. 135 hal.

Tampubolon, T. P., E. I. Raharjo., dan Farida. 2016 Pengaruh Beberapa Jenih Pakan Alami Terhadap Pertumbuhan dan Kelangsungan Hidup Larva Ikan Koi (Cyprinus carpio). Fakultas Perikanan dan Ilmu Kelautan, Univesitas Muhammadiyah Pontianak. 7 Hal.

Utomo, N. B. P., P. Hasanah dan I. Mokoginta. Pengaruh Cara Pemberian Pakan yang Berbeda Terhadap Konversi Pakan dan Pertumbuhan Ikan Mas (Cyprinus carpio). Institut Pertanian Bogor. Jurnal Akuakultur Indonesia, 4(2). Hal. 51.

Wiryanata, W. 2010. Budidaya dan Bisnis Ikan Nila. Agromedia Pustaka. Jakarta. 112 hal.

Zairin Jr, M., R. K. Sari dan M. Raswin. 2005. Pemijahan Ikan Tawes Dengan Sistem Imbas Menggunakan Ikan Mas Sebagai Pemicu. Jurnal Akuakultur Indonesia 4(2): 103-108.

Zonneveld, N., E. A. Huisman., And J. H. Boon. 1991. Prinsip-Prinsip Budidaya Ikan. PT. Gramedia Pustaka Utama. Jakarta. 317 hal. 